\title{
A Religious Media Revolution? The Syrian Conflict and Mediated Sunni Authority
}

\author{
Jakob Skovgaard-Petersen
}

Media and revolution are two words often combined. Not only do we regularly speak of the introduction of new media as revolutions, we are also well aware that media are a crucial component in the spreading of a political revolution. In a Middle Eastern context, this was well captured in Annabelle Srberny's classic book, Small Media, Big Revolution (1994) on the role of cassette tapes of Imam Khomeini's sermons during the Iranian revolution. And it has been a vivid, if contested, theme in the analyses of the successful mobilization of youth in the Egyptian revolution of January-February 2011. While it would be a preposterous example of techno-determinism to claim that these political upheavals were somehow caused by new media technology, it would be equally absurd to deny that the new media gave the organizers new means of mobilizing and directing their fellow demonstrators, documenting regime violence, and disseminating their interpretations to the international community.

This has been equally in evidence in the case of the Syrian uprising, which began in March and April 2011. In Syria, the regime's control of traditional print and audiovisual media was close to complete, and Internet companies were owned by people from the inner circles of the regime. Even so, the mobile phone with a satellite connection empowered citizens to communicate, document and upload messages to media beyond the country's borders, and beyond the reach of the regime. These technologically innovative and artistic dimensions of the Syrian uprising have been studied and celebrated in numerous publications. It is, however, still difficult to assess their impact in 
the real world, as the war has been grinding on between the regime and rebel militias, most of the latter not in any close connection with the early media activists.

This paper aims at investigating the use of the new media by Sunni religious authorities, and the transformations of religious communications that this has implied. This is done by tracing the introduction and development of new media by religious actors, and by looking into the kind of authority these actors seek to embody, whether regime supporting, oppositional or jihadist. Moreover, the paper will look into the particular genres employed, and how these have changed. While this is only a preliminary investigation, it points to both the introduction of new genres and transformations of classical genres of Islamic communication, such as khutab, anashid and fatawa.

\section{Uprising and media revolution}

Even by the standards of the Arab World, Syria before the uprising was a media backwater. As a media system it was characterized by Rugh (1979) as 'mobilizational', in that the state owned the media and the regime employed them to push for a political transformation of society and its inhabitants. Shortly after the take-over of Bashar alAssad from his father Hafez in 2000, a liberalization of the media had been initiated but swiftly abandoned. Ever since the emergence in the 1990s of the "New Arab Public Sphere', Syria had remained on the sidelines (Lynch 2006; 2015). No powerful panArab television station was based in the country, and pan-Arab newspapers tended to ignore it, due to difficulties in getting reliable information from the authoritarian regime and its administration. All really powerful media were owned by the state, and cronies of the regime controlled the few private newspapers. Only in the production of TV dramas had private Syrian producers made their mark, but this was as suppliers to the major Gulf and Lebanese TV stations.

The uprising was to change all this. While initially the state media continued as if they were still the sole purveyor of news from the country, foreign media took a keen interest in the unfolding of the (initially peaceful) protests. Hesitant at first, also the two main Arab news channels, al-Jazeera and al-Arabiyya, covered the uprising with a clear sympathy with the protesters, much to the anger of the Syrian regime and Bashar alAssad personally. Using satellite connections from their smartphones, the activists were 
in direct contact with oppositional or foreign news services based outside the country, using the connection for documentation of regime attacks, but also for mobilization, coordination and strategic communication. Regime supporters set up private channels, as did opposition figures based in the Gulf. More importantly, Iran and its ally Hizbollah mobilized their media operations in support of the Syrian regime.

If the Syrian media had been state-controlled, unimaginative and underdeveloped, this was of course the case with religious media as well. Officially secularist, during the years of president Bashar al-Assad (2000- ) the Syrian state and its leading Baath party had come to accept a certain measure of religious activism and visibility. Through publications and annual conferences it promoted the idea of a certain Syrian religious conservatism across the various religions and a message of inter-religious tolerance. But given its ban on the Muslim Brotherhood, and its general awareness of the political potential of Sunni Islamism, the regime was not interested in Islamic proselytism. For decades, the only Sunni religious publication allowed was the monthly Nahj al-Islam, published by the Ministry of Religious Endowments.

Still, this happy state of keeping the citizenry uninformed by alternative interpretations of events was not to last. The satellite media revolution meant that Syrians could choose between hundreds of television channels to watch, and the regime could do nothing about it. By the time of the uprising, there were some 1320 satellite channels broadcasting in Arabic, some $10 \%$ of which could be defined as Islamic, most of them Sunni Muslim (Galal 2014, 9-10). Especially from around 2007, channels proselytizing a Salafi (puritan) version of Islam were established in Egypt and Saudi Arabia and reaching audiences in all over the Arab World, unnerving Arab regimes. While the Syrian regime was staunchly anti-Islamist, like many other regimes it was mainly suspicious of Islamist media, and perhaps less concerned about the seemingly a-political Salafists (Pierret 2011, 134). Moreover, since the early 2000s, the Syrian secret services had a working relationship to some of the Salafi-Jihadi groupings in Lebanon and Iraq (O’Bagey 2012, 13-15).

Hence, already prior to the uprising, the Syrian regime felt under pressure to respond to the increasing amounts of Islamist and Salafi daawa (mission) entering the country by way of satellite television or the Internet. In addition to the Ministry's homepage, leading religious personalities loyal to the regime all opened their personal 
websites; most importantly the grand Mufti of Syria Ahmad Hassoun, the leading TV preacher Said Ramadan al-Buti, and the popular radio preacher Rateb al-Nabulsi. Furthermore, in a private initiative a more advanced website, Naseem al-Sham, was introduced with an interactive fatwa service and the khutab (Friday sermons) of the major preachers, both on PDF and in audio.

Al-Buti, in particular, had a long history of countering abstract Salafism and posing a more grounded, traditional Islam in its stead, based on the theo-juridical tradition of Ash `ari-Shafiism that most Syrians would belong to (Pierret 2011, 99-106). He had a significant following and was rewarded for remaining loyal to Hafez, the father of president Bashar al-Assad, during the preceding Islamist uprising in the early 1980s. When the 2011 uprising began, al-Buti was once again in a position to extract concessions from Bashar for his continued and vocal support against an uprising the bulk of which were Sunni Muslims. One of his demands was an official Sunni TV-station, Nur alSham, which was instantly granted and opened in August 2011. As the name, 'Light of Damascus' indicated, the idea was to fend off Salafi and Islamist propaganda by means of a counter-propaganda based on the claim that these other renderings of Islam belong in the Arab Gulf and are alien to the religious traditions of the Syrians. The channel opened with a seminar featuring al-Buti, the Mufti and the Minister of Religious Endowments discussing the "aggression against Islam" conducted partly by the West and partly by Gulf preachers (al-Buti 2011a).

In March 2013 al-Buti, aged 83, was killed by a small bomb while teaching in a mosque in Damascus. The circumstances of his death are murky, as the national TV showed unconvincing photos of a suicide bombing, but it is difficult to understand why the regime's men would kill him. During the first two years of the uprising, al-Buti had unflinchingly supported the regime in sermons and fatwas. Some of his fatwas to the Nasseem al-Sham website reflect the degree to which violence was creeping into the sphere of religious authority and moral guidance; from his allowance of forced prayer on rugs with the portrait of the president, to a fatwa absolving a soldier who had shot indiscriminately into crowds of demonstrators to (al-Buti 2011a).

Al-Buti's fatwas are examples of how violent conflict gradually made its way into religious genres normally void of violent content, and how it is now distributed through new media. Soon, the top Sunni religious figures of the regime were fully involved in 
the mobilization, declaring jihad and threatening the rebels. The Mufti, Ahmad Hassoun, who lost a son to the rebels in 2012, issued a declaration of jihad against the uprising (al-Tamimi 2013). He also threatened Europe with terrorism and is alleged to have permitted the killing of civilians (SA 2015).

The revolution will be YouTubed - and turn violent

In the opposition, an early example of this entrance of conflict into established Islamic genres were the YouTube sermons (khutba) first 'berating' the ruler to change his way (nasiha), and later denouncing him altogether in a sermon known as 'a word of truth' (kalimat al-haqq). Within months of the uprising, local men began to arm themselves, often in alliance with defectors from the army. Bands, units, battalions and the like announced themselves on YouTube, often with Islamic names and shouts of 'God is great'. First employed to film regime violence on and upload the videos for documentation, smartphones and YouTube became the medium of choice for Syrian activists, offering instant production, high credibility and swift distribution. This also meant a renaissance for classical Islamic genres that had suffered under the print-driven public dissemination of the $20^{\text {th }}$ century: the khutba, but also religious hymns (anashid) and Qur'anic recitation (qara'a). YouTube sermons began to circulate with more radical Salafi preachers calling the believers to arms against the enemy - now also named by religious, rather than political, affiliation. The regime and its supporters were called Nosayris (an older word for Alawite, implying that they are following their own religious founder, and not Ali), and their Iranian backers were called Safavids (evoking the $17-18^{\text {th }}$ century confrontations between the Sunni Ottoman and the Shia Safavid empires).

The most prominent of the early Sunni religious warmongers on the rebel side was Adnan al-'Ar'ur. A Salafi sheikh from Hama in exile in Riyadh, he was a fierce critic of the Assad regime long before the uprising broke out. Broadcasting from Riyadh, he called for war against the Alawites and Shia, thus actively working to turn the uprising into a sectarian struggle for the control of Syria. Al-'Ar'ur had a program on a TVstation which was then further distributed via his website, Facebook, Twitter and YouTube accounts. 
Sheikh al-'Ar'ur is a relatively rare example of a Muslim scholar ('alim) taking full advantage of the new media. Most ulama would not know how to do that, and the main regime preachers such as al-Buti and Hassoun merely had people (of another generation) to help them. It could be argued that the very fact that ordinary media outlets were closed to the oppositional sheikhs meant that they were forced to explore the new media whether they wanted to or not. The distance from Syria, as well as the money and media technology available in the Gulf capitals (Salafis typically in Riyad or Kuwait City, Islamist sheikhs typically in Doha), further enabled them to move into the new media. Without the spread of the smartphone in Syria (and constant struggles to secure electricity to load it), it would have been of little impact on the ground. As it were, in the rebelcontrolled areas the new media hardly competed with the old ones, but simply filled a void.

\section{Enter ISIS}

From small beginnings in 2012, jihadist militias began to focus on Syria, and from 2013 they also made themselves noticed in the cyber sphere. Much has been written of the media savvy of ISIS or, after July 2014, Islamic State (IS). Comparing its media operation with that of al-Qaeda at the time of Osama bin Laden (who was killed in 2009) illustrates how far they have come. While al-Qaeda in Afghanistan produced gritty video tapes that were smuggled long roads to the correspondent of al-Jazeera who then decided whether to broadcast them or not, IS produces state of the art films, glossy magazines and news reels from every province and distributes dozens of them daily and instantly via the internet where they are reproduced and republished by supporters all over the world. Nevertheless, in his day, and with his more simple videos, ways Osama bin Laden was actually able to set the jihadist agenda as decisively as has IS, and right now al-Qaeda has geared up its media operation to match that of IS.

But there are other differences between the two groups' media strategy. Not least the way whereby they established and embodied authority. In al-Qaeda's videos of the early 2000s, it was Osama bin Laden who spoke. He was embodying al-Qaeda, and his style was calm and dignified; he was to project reason and self-control to convince the listener that he knew what he was doing. Such videos are still coming out from alQaeda with his successor, Ayman al-Zawahiri. In contrast, IS has only released a single 
video of its leader, Abu Bakr al-Baghdadi, and that was his inaugural sermon as caliph from Ramadan (July) 2014, calling for jihad. It was homiletic and ceremonial, demonstrating his authority rather than arguing for it.

Instead, IS videos serve action. We witness IS men preparing for attacks, engaging in battles, blowing up ancient buildings, hunting Shiites, executing prisoners. They are many, often anonymous. But we also see interviews with them, we se them patrolling, interacting with citizens, teaching children, training prospects, taking people to court. And we see them relaxing, drinking tea, playing games, even swimming: an active, fulfilling life in the newly established but already god-fearing and harmonious state. Reasoning of the Osama bin Laden kind does appear, as well, but mainly in audios of the speeches of Abu Muhammad al-'Adnani, the official spokesman who was killed in the summer of 2016. The videos, however, have a different story to tell. Namely: come to the lands of the believers; you will be welcomed and valued, get friends and a family, and a higher sense of purpose. This is also stressed in the interviews with fighters who have arrived from Europe and who confess about a sinful life among sinful people, with the subtext: you are probably a nobody, so come and become a somebody. IS, of course, had a territory to reign and arm.

IS also publishes an online magazine in English (Dabiq), in French (Dar al-Islam), in Arabic (an-Naba) and similar ones in Turkish (Kunstantiniyya), Russian, and other languages, all very well produced. Since 2010 al-Qaeda has done the same, albeit more irregularly, producing first Inspire and from 2014 Resurgence, which has however only appeared in two, issues. The differences in strategy between al-Qaeda's and IS's magazines have been analyzed and compared to Dabiq by Celine Novenario who points out that al-Qaeda employ attrition directed towards the West, whereas Dabiq is mainly concerned with recruitment to the caliphate, but also strongly overbids when it comes to violence and intimidation (Novenario 2015). It should be added that when in 2016 IS was forced on the defensive, it changed its strategy towards recruitment of fighters who would stay and conduct attacks in Western countries.

Taking advantage of the ease of online distribution, the magazines are designed to look like offline magazines, but the al-Qaeda magazines seem mainly to be for the already convinced. The latest issue of al-Qaeda's Resurgence is a 90-page interview with 
a martyred Western jihadi Adam Gadahn. Articles in the IS magazines are much shorter, and come with many, often violent, illustrations.

IS has also initiated an online publication of the works of Muhammad ibn Abd alWahhab. Abd al-Wahhab, a puritan preacher in $18^{\text {th }}$ century Arabia, is clearly an inspiration to IS. But he is, of course, also the founder of Saudi Arabia's brand of Islam. Publishing and disseminating him is thus a claim to his legacy, directed against Saudi Arabia, which is considered a special enemy by Islamic State (Bunzel 2016, 1; 8).

The main jihadist media activity today is comprised of videos or small statements produced on PDF as press releases. These have, however, grown exponentially, with both IS and Jabhat al-Nosra, its Syrian rival, releasing up to ten videos daily, as registered by the clearing house website Jihadology.net. Most of these are about feats at the front, but others are about more peaceful, but still ideologically relevant activities. During Ramadan of 2016, Jabhat al-Nosra ran a daily series of major battles won by Muslims during Ramadan, and another series about the district da 'wa offices in its territory. IS, on the other hand, has continued long-term broadcasts of anashid (male choir) and qara'a (recitation of the Qur'an). In Ramadan, its various 'governorates' published small videos of battles on longer thematic films for instance on 'Guiding the people', and 'Marking the second anniversary of the caliphate'.

The media operations of IS are extensive. According to its self-description, published by its official media company, al-Furqan, the media operations are administered by the Media council (diwan al-i'lam) which is one of 14 governmental councils in the state (Islamic State 2016b). Apart from the above-mentioned magazines, it also runs a $\mathrm{TV}$-station, a string of local radio stations, a translation bureau and media training courses. In June 2016 one of its media outlets, Wilatyat al-Khayr, also published a film about the media war waged against the Islamic Stat and how IS is responding to it. Entitled 'Revelations of Satan', the video introduced five men who had reported to the outside world about their city, Deir az-Zor, under IS rule, allegedly for dollars (Islamic State 2016a). We see them confess and then executed, either having their throat slit, or being tied to their laptop or camera which is then wired and blown up. In between these five executions, a speaker tells about the first traitors at the time of the prophet and how they were dealt with, and at the end the video provides data about the media operations of IS, including its more than 40 affiliated media bureaus. 
What, then, about religious authority? According to IS, there is one man who has the real religious authority, namely its caliph, Abu Bakr al-Baghdadi. Apart from his inaugural khutba he has only communicated sparsely, via audiotaped speeches. He is, however, frequently quoted in IS material. More common, but still rare, are the speeches of IS spokesman, Abu Muhammad al-Adnani, also in the form of audio files. Neither man would count as a religious authority outside IS circles, although al-Baghdadi has a degree from a religious institution in Iraq. Overall, IS has had difficulties in appealing to ulama from outside its own organization. The nomination of al-Baghdadi for caliph was entirely done by IS own ulama who are not recognized as Sunni authorities of status outside the group. Major ulama networks, nationally and internationally, have vehemently condemned it. Even well known jihadist sheikhs have disowned it and engaged in polemics against it, and major polemics between IS and al-Qaeda have ensued (Skovgaard-Petersen 2016). This is easily explicable in the propaganda of IS which has devoted considerable space to denounce the false, weak and docile ulama of this world; holding a doctorate or other degree from a university outside the IS is not, in its view, a proof of learning but of corruption. It is, however, not beginning from scratch. Theologically, it professes a dogmatic position ( 'aqida) more or less in line with al-Qaeda and other Salafi currents. In law, it also follows in the footsteps of that tradition, and especially the above-mentioned Muhammad ibn `Abd al-Wahhab, taking its sentences and punishments much further than what Salafi-Jihadi groups have generally done. It will, however, still argue with Qur'an verses and ahadith, and commentaries on these verses by renowned classical scholars, thus demonstrating a faithful attitude to tradition and implicitly accusing its critics of deviating from it, for instance on the issue of slavery.

\section{Conclusions}

Ten years ago, practically all media material produced in Syria was directed and disseminated by the regime or its trusted men, and the regime had the will and competence to monitor and control it. Syrians had, by and large, come to live with this system, even if few of them believed that regime media conveyed a truthful picture of all events. It must therefore have been a confusing experience to witness the proliferation of media espousing very different views of the world. 
We have followed the dramatic expansion of media in Syria, from near to complete state control over the intrusion of pan-Arab satellite television to the emergence of oppositional outlets and rebel media. And finally to the establishment of a rival state entity on Syrian territory, complete with its own media ministry and a plethora of channels, broadcasts and Internet outlets. The Islamic State is, of course, even more top down and in control of the media scene than the Baath party ever was, and in terms of media systems IS territory may qualify as a totalitarian media system, intent on making people in its territory believe and act on its propaganda, rather than merely disciplining them to acquiesce in the official rhetoric (Wedeen 1999, 74-75).

Nowhere will this have been felt more keenly than in the field of Sunni Islam. This was one of the areas where the regime was most watchful, and most restrictive. Nevertheless, even in this area change was in the airwaves even before the uprising of 2011. At the time of the uprising, important international TV sheikhs broadcast by specifically religious channels (and by the dominant channels al-Jazeera and MBC1) had found an audience inside Syria and were preaching versions of Islam at variance with the one propagated by the Syrian regime's own sheikhs. When the uprising began, Syrian sheikhs began to make opposition moves, as well, and found new and more forceful ways of getting their message through. The mediated sermon witnessed a revival, as new media broadcast much more political and emotional preaching. The longer literary genres gave way to oral and aural genres such as singing and the recitation of the Qur'an.

Since 2011 Sunni religious media, programs and content have come to the fore, and been at the fore, of public attention, concern, and scare. Within months of the largely peaceful demonstrations, more sinister religious messages were being spread by certain actors on the opposition side and, as we have seen, also by some of the Sunni authorities supporting the regime. Religious legitimation of fighting and killing became the norm on both sides of the political contestation, and not only among the Sunni Muslims. This led to a rise in Sectarian killings and paved the way for truly chauvinist and jihadist Sunni (and Shia) media.

The Islamic State and Jabhat al-Nosra, the two most important Sunni jihadi militias, have ventured into internet media on a massive scale and with impressive, and truly frightening, results. Employing their own brand of Salafi Jihadi ideology, they have 
revolutionized Islamic media messaging at many levels. These are violent movements within a long tradition of Islamic revivalism. They are, however, not led by religiously charismatic figures, and although they do have ulama supporters, formal religious authority is not a point of strength for them. Rather, they launch the same kind of virulent criticism of the existing ulama in Syria and Iraq, as they reserve for these countries' political leaders. Their religious claims are vested in videos of their institutions and fighters, not in the promotion of religious leaders. This is potentially a point of weakness, and may also indicate a way for Muslim ulama to overcome a Sunni religious crisis that they, as much as anyone, have a responsibility to end.

\section{References}

Alterman, J 2011, 'The Revolution Will Not Be Tweeted', in The Washington Quarterly, vol. 34, no. 4, pp. 103-116.

Bunzel, C 2016, The Kingdom and the Caliphate. Duel of the Islamic States, Washington, Carnegie.

Al-Buti 2011a, Symposium in the Nur al-Islam channel. Available at: https://www.youtube.com/watch?v=MeSz7zvhcIs [Accessed November 24 2016].

Al-Buti (2011b), Fatwa on shooting into crowds. Available at: http://www.naseemalsham.com/ar/Pages.php?page=readFatwa\&pg_id=14375\&bac $\mathrm{k}=8913$; [Accessed November 24 2016]

Galal, E (ed.) 2014, Arab TV-Audiences. Negotiating Religion and Identity, Frankfurt AM, Peter Lang Verlag.

Islamic State 2016a, Wahy Shaytan. Available at: http://jihadology.net/2016/06/25/newvideo-message-from-the-islamic-state-revelations-of-satan-wilayat-al-khayr/ [Accessed 24 November 2016]

Islamic State 2016b, The Structure of the Caliphate. Available at: http://jihadology.net/2016/07/06/new-video-message-from-the-islamic-state-thestructure-of-the-caliphate/ [Accessed November 24 2016].

Lynch, M 2006, Voices of the New Arab Public, New York, Columbia University Press.

Lynch, M 2015, 'The Rise and Fall of the New Arab Public Sphere', Current History, pp. 331-36.

Novenario, CM 2016, 'Differentiating Al Qaeda and the Islamic State through Strategies Publicized in Jihadist Magazines', Studies in Conflict and Terrorism. DOI: 10.1080/1057610X.2016.1151679

O’Bagey, E 2012, 'Jihad in Syria', Washington: Institute for the Study of War. Available at: 
http://www.understandingwar.org/sites/default/files/Jihad-In-Syria-17SEPT.pdf [Accessed 24 November 2016]

Pierret, T 2011, Baas et Islam en Syrie, Paris, Puf.

Rugh, W 1979, The Arab Press, Syracuse: Syracuse University Press.

SA 2015, 'Ahmad Badr al-Din Hassoun - dhabit al-mukhabarat bi rutbat mufti'. Available at:

http://aawsat.com/home/article/342446/\%D8\%A3\%D8\%AD\%D9\%85\%D8\%AF\%D8\%A8\%D8\%AF\%D8\%B1-\%D8\%A7\%D9\%84\%D8\%AF\%D9\%8A\%D9\%86\%D8\%AD\%D8\%B3\%D9\%88\%D9\%86-\%D8\%B6\%D8\%A7\%D8\%A8\%D8\%B7$\% \mathrm{D} 9 \% 85 \% \mathrm{D} 8 \% \mathrm{AE} \% \mathrm{D} 8 \% \mathrm{~A} 7 \% \mathrm{D} 8 \% \mathrm{~A} 8 \% \mathrm{D} 8 \% \mathrm{~B} 1 \% \mathrm{D} 8 \% \mathrm{~A} 7 \% \mathrm{D} 8 \% \mathrm{AA}-$ $\% \mathrm{D} 8 \% \mathrm{~A} 8 \% \mathrm{D} 8 \% \mathrm{~B} 1 \% \mathrm{D} 8 \% \mathrm{AA} \% \mathrm{D} 8 \% \mathrm{~A} 8 \% \mathrm{D} 8 \% \mathrm{~A} 9-$ $\% \mathrm{D} 9 \% 85 \% \mathrm{D} 9 \% 81 \% \mathrm{D} 8 \% \mathrm{AA} \% \mathrm{D} 9 \% 8 \mathrm{D}$ [Accessed 24 November 2016]

Skovgaard-Petersen, J 2014, 'New Media in the Muslim World', The Oxford Encyclopedia of Islam and Politics, vol. 2, pp. 183-88.

Skovgaard-Petersen, J 2016, 'Arven fra Abu Bakr. Om historieopfattelse og ideologi hos Al-Qaeda og IS', in: Splittelsen i Global Jihad, Copenhagen, DIIS Forlag.

Sreberny, A and Mohammedi, A 1994, Small Media, Big Revolution: Communication, Culture, and the Iranian Revolution, Minneapolis, University of Minnesota Press.

Al-Tamimi, A 2013, 'Jihad in Syria (Part II): The Assad Regime Perspective', in Syria Comment, Available at: http://www.joshualandis.com/blog/jihad-in-syria-part-iithe-assad-regime-perspective-by-aymenn-jawad-altami$\mathrm{mi} /$ ?utm_source $=$ feedburner\&utm_medium $=$ email\&utm_campaign $=$ Feed $\% 3 \mathrm{~A} \% 20$ Syriacomment $\% 20 \% 28$ Syria $\% 20$ Comment $\% 29$

Wedeen, L 1999, Ambiguities of Domination, Chicago, University of Chicago Press. Winter, C 2015, Documenting the Virtual 'Caliphate', London, Quilliam Foundation. 